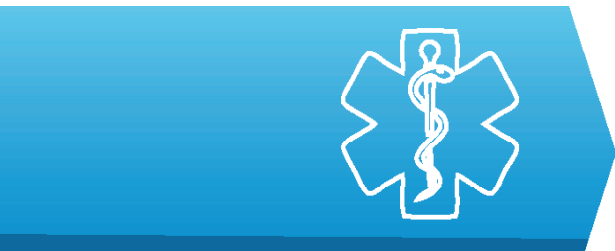

HISTORY OF MEDICINE AND PHARMACY

1) Department of Oral and CranioMaxillofacial Surgery, Iuliu Hatieganu University of Medicine and Pharmacy, Cluj-Napoca, Romania

2) Department of Medical Education, Iuliu Hatieganu University of Medicine and Pharmacy, Cluj-Napoca, Romania

\section{Landmarks in the history of Oral and Maxillofacial Surgery in Cluj-Napoca, Romania}

Alexandru Rotaru ${ }^{1}$, Cristian Bârsu², Horaţiu Rotaru ${ }^{1}$

\begin{abstract}
At the anniversary of a century since the establishment of medical higher education in the Romanian language, the authors present the personalities who shaped the future of dental surgery within the specialty of dental medicine, and then of the oral and maxillofacial surgery as a branch of stomatology, followed by the establishment of surgery as its own specialty and discipline. The evolutionary stages, difficulties and successes achieved by this specialty are presented through the various historical landmarks of the last century.
\end{abstract}

Keywords: maxillofacial surgery, history of medicine, Romania

To emphasize the connection between Surgery and Dentistry, the famous professor of surgery, Iacob Iacobovici, the founder of the surgical education in Cluj, repeatedly stated that Dentistry has entered into Medicine through Surgery. He saw this happening with his own eyes on the occasion of the Balkan War when he led the Sanitary Service of the Romanian Army on the Bulgarian front. Then, he realized that the most dramatic war injuries were to the face, jaws and oral cavity [1].

The founder of the dental education in Cluj and Romania, Professor Gheorghe Bilaşcu, before majoring in Dentistry, reached a thorough surgical training working in Budapest, in various institutions with this profile. One of his great personal achievements was reached while on duty at the Orthopedic Hospital, when he was confronted with a case of massive bleeding that he stopped using the turpentine rectified oil. The surgical method was a great inspiration because this product had not been used before for this purpose. Further on, hemostasis through the use of this product has been extended to all surgical profiles, but especially in dentistry [2].

Oral and maxillofacial surgical pathology was included in the dental specialization of Dr. Bilaşcu. This fact is attested by his numerous scientific works, as well as by the topics of courses and internships with students and doctors specializing in Dentistry.

His successor at the chair of the Chair and Clinic ofDentistry, Ioan Aleman, further developed the surgical branch of Dentistry. In fact, his professional beginnings were in the field hospitals in Brno, Neuburg and Vienna, profiled on the oral and maxillofacial surgical pathology. Although he had only the role of doctorhelper (Hilfsartz), being still a student in the last year of the Hungarian Faculty of Medicine in Cluj, he accumulated a substantial amount of surgical knowledge in the oral and maxillofacial profile, which subsequently stimulated his interest for this part of the pathology. The fact mattered in his option after the end of the war, when he was part of the Romanian Commission to take over the Dental Laboratory from the Hungarian Faculty of Medicine, a laboratory in which students were optionally trained in stomatology.

After completing his studies at the new Romanian Faculty of Medicine in Cluj, Aleman was noted by Professor Dr. Gheorghe Bilaşcu due to his knowledge in this branch of dentistry, and consequently he was employed as probation assistant at the Dental Clinic.

His surgical skills did not go unnoticed by the head of the Clinic either. As a result, Professor Bilaşcu obtained him 
a one-year scholarship to the "Kiefferabteilung" Oral and Maxillofacial Surgery Section in Vienna, led by Prof. H. Pichler, in whose service he had worked during the war [3]. Having a good knowledge of German and of the "customs of the house", in a short period of time, he accumulated a large amount of knowledge in the field.

Returning to the Dental Clinic in Cluj, Dr. Aleman put his knowledge to the fore. As a result, the professor promoted him from Assistant to Lecturer. Soon after the breakthrough, followed the dramatic episode of the death of the head of the Clinic, Professor Dr. Gheorghe Bilaşcu. In that situation, Dr. Aleman was forced to take over the professional prerogatives of the Chair and Clinic of Dentistry, which gave him the opportunity to validate his potential in the specialty.

He was particularly attracted to the surgical part of Dentistry, but without neglecting the purely dental one. Extending much the area of oral and maxillofacial surgery, he was often put in the situation to rely on the infrastructure of the surgical clinic, led by the famous Professor Dr. Iacob Iacobovici, a personality known and appreciated in Europe at that time [4].

The surgical problems of the head and neck, including the maxillofacial ones, were resolved at that time by the general surgery surgeons and Prof. Dr. Iacobovici knew them well. He was among the first 5 European surgeons who performed with good results a complete resection of the mandible. Therefore, at the Surgical Clinic, Dr. Ioan Aleman found not only the necessary infrastructure, but also a good counselor, in the person of Professor Iacobovici.

The fact that Ioan Aleman combined the surgical treatment with the prosthetic (dental) treatment made his results better than those of the general surgeons who also addressed this field. The latter rejected the idea of the need for oral and maxillofacial surgical treatment combined with dental (prosthetic) treatment.

Regarding such conduct, in a 1934 paper entitled "Resection Prostheses" Ioan Aleman made the following comment: "There are still surgeons today," says Ernst (great German plastic surgeon nn), who avoid being poisoned by the collaboration with a dentist in the maxillary resections. Perhaps Ernst's statement is a bit exaggerated, however, we were also able to see cases where before the surgery, the surgeon did not even want to think that dentists even existed and only after unsuccessful attempts to repair the operative defect asked us to perform the miracle of rendering the patient, who had been mistreated for months, an aesthetic aspect" [5].

In the meantime, things have evolved. Dr. Aleman, through his surgical talent, expanded the limits of oral and maxillofacial surgery, and Professor I. Iacobovici, who had hosted him in his clinic, and even advised him in many cases, noted the progress and increased efficiency of the techniques used by Ioan Aleman. This fact has led to a fundamental change in the way the respective pathology is viewed by the specialists in general surgery.

The great Professor I. Iacobovici himself oriented the oral and maxillofacial surgical pathology towards Ioan Aleman. This orientation was based on the superior postoperative results obtained by combining surgical and prosthetic methods [6]. Professor Ioan Aleman, with his sharp mind, had personal surgical methods and ingenious ideas in the making of prosthetic devices meant to support the operative act and to direct the healing.

The scientific works elaborated or guided by Professor Ioan Aleman were also appreciated internationally. One of the doctoral works elaborated in the Dental Clinic in Cluj, under his direct guidance, was evaluated by Prof. Victor Veau, the most prestigious plastic surgeon in the world at that time, in the problem of cleft (cracks) of the labia-maxilla-palatines. He sent the following appreciation to Aleman: "I congratulate you on a story that inspired Klima's thesis. This is one of the most beautiful works I have ever seen on this subject" [7]. It was an implicit acknowledgment of the value of the thesis supervisor by a world renowned expert in the matter.

The value of the specialization courses that I. Aleman held was also underlined by the participation of some European personalities, as lecturers. Professor Lindemann from Germany, a renowned figure not only for his contributions in the field of oral and maxillofacial surgery, but also through a series of surgical instruments bearing his name, was among them. Professor Lindemann presented the topic "News in oral and maxillofacial surgery". It was in 1938.

The period that followed was one of the preparation and deployment of the Second World War, the Refuge of the Faculty of Medicine and the clinics in Sibiu, as well as their return in 1945. In 1948, Professor Ioan Aleman died prematurely at the age of only 57 years.

The year 1948 coincided with that of the Education Reform. After that, Higher Education, including medical education, took on the image and likeness of the Soviet Union.

It seems paradoxical but, for the Higher Dental Education, this reform was a strike of luck. The Faculty of Dentistry was set up, which included the Department of Oral and Maxillofacial Surgery. It has come off as a discipline and an independent specialty, from the Department of Dentistry of the old Faculty of Medicine. Through this detachment it took its own path, with new opportunities for development. Obviously, all was done within the limits allowed by the economic and political conditions of that time. However, a new perspective emerged.

In spite of all the ills that have accompanied this reform, the Higher Dental Education in Romania has been regarded with respect by those in the West, at least in the first years. Until then, representative human values had been gathered, which, after the Reformation, took over the destiny of this medical education.

The department and the Clinic of Oral and 
Maxillofacial Surgery had a specific characteristic, which required a double training: surgical and dental. In the country there were only two people who met these requirements, Dr. Cornel Tiberiu Opriş in Cluj and Dr. Valerian Popescu in Bucharest. Tiberiu Opriș had a specialization in Germany, with Prof. Wassmund, in Berlin, and in Austria, in Vienna, with Professor Pichler. In both clinics, besides oral and maxillofacial surgery he had also learned plastic surgery of the head and neck region [8].

During the war, Dr. Opriş consolidated his specialized knowledge within the Campaign Hospital 303 in Craiova, a sanitary unit under the supervision of Maria Antonescu, the marshal's wife. It was a well-equipped unit that provided specialized healthcare for civilians as well [9].

After returning to Cluj from the Refuge in Sibiu, together with the Faculty of Medicine, in addition to his activity at the Department of Physiology, Dr. Opriş also volunteered in various clinics, where he maintained his performances acquired until then, in oral and maxillofacial surgery.

With the establishment of the Faculty of Dentistry (1948) and, within it, of the Chair and Clinic of Maxillofacial Surgery, the professional career of Dr. Opriş entered a specific domain, being named the lecturer and the head of the clinic [9].

The prerogatives of the function of chair and clinical head involved the accomplishment of two decisions. One was represented by the formation of a group of academic staff who could fulfill both the teaching and the hospital function and the other was the arrangement of a clinical space, for the patients with oro-maxillofacial disease, and didactic, for the students and doctors who were going to specialize in this surgical branch. In both cases, the lecturer, Dr. C. Opriş, had great difficulties.

But those that seemed insurmountable were those related to the clinical and teaching space. For 10 years, this problem was delayed by the local political and administrative authorities who offered for the Faculty of Dentistry, including Maxillofacial Surgery, totally inadequate buildings in terms of location, hospital capacity and the relationship with the other clinics.

In 1958, on the occasion of the opening of the academic year, the Head of State, Gheorghe Gheorghiu Dej and the Prime Minister, I. Gh. Maurer were present in Cluj. On that occasion, by a brave and unexpected gesture, the head of the Chair and Clinic of Oral and Maxillofacial Surgery, Associate Professor. Dr. Opriş, appeared instantly in front of the official convoy, with an envelope in his hand, in which there was a request for an appropriate space for the entire Faculty of Dentistry and, implicitly, for the needs of the Chair and Clinic of Oral and Maxillofacial Surgery [9]. The Prime Minister, a wise man, took into account the demands of the university, an educational institution. He gave the necessary provisions, and the result was the obtaining of the building in Cluj-Napoca, no. 33 Moților
Street, where it still functions (a part of it), at present.

Established in the new location, the clinic has benefited from good conditions, both on the ambulatory and on the stationary side. In this way, the educational base has allowed to carry out a didactic activity at the desired level. The dental students from Cluj-Napoca became familiar with the concepts and maneuvers of ambulatory oral surgery, so that, more than the ones from the similar clinics in the country, they applied them in the field after the assignment to the jobs.

Doctors who were also teachers have acquired, theoretically and practically, the necessary knowledge for a specialist doctor. In addition, compared to colleagues from similar faculties in the country, they have acquired certain maneuvers imposed by the Head of the Department and the Clinic, such as the exploratory and evacuation points in the suppurations located in the deep slits of the face or the methods of stimulation of the bone regeneration in the maxillary fractures, bone cystic tumors or periodontics.

Prof. Dr. Corneliu Tiberiu Opriş was also a great researcher. While working at the Department of Physiology, along with Professor Grigore Benetato, they performed numerous scientific works related to Dentistry and Oral and Maxillofacial Surgery. In physiology, he performed the canine double-cross experiment, by which he canceled the myth of the uniqueness of the Pavlovian nervous regulation of the body's functions, demonstrating the existence of a humoral mechanism.

This mechanism was intuited by the great scientists of the world who tried to prove it experimentally, but did not succeed, because all the experimental animals died in the surgical preparation phase. Professor Opriş, with remarkable surgical skills, was able to complete the experiment and make his public demonstration at the World Physiology Congress in Brussels, 1956. The success of the Romanian researchers changed the world thinking in physiology because they settled in its logic the humoral mechanism for regulating functions [9].

On the other hand, Professor C. Opriş also made important contributions to Maxillofacial Surgery. By way of example, we can mention his method of diagnosis and treatment by exploratory and evacuation puncture of the suppurations located in the deep lodges of the face; 30 years after his announcement that bone regeneration is faster in the rigidly immobilized bone fracture outbreak, this conclusion was confirmed by researchers in German literature $[10,11]$.

The use as stimulants of bone regeneration of calcium phosphate preparations was made by Prof. Opriș, well before others. Under his leadership, Dr. Marius Rimbaşiu has completed his $\mathrm{PhD}$ thesis on the subject. There could be many other examples that, in fact, positioned Oral and Maxillofacial Surgery in Cluj-Napoca until 1974 in the European mainstream of the specialty or, at least, close to it. 
A period of stagnation followed, between 19741989, due to the economic and political conditions that brought with them a severe austerity and an equally drastic limitation of the relationship with the West and implicitly of the professional-scientific advances. During this time the management of the Department and the Clinic was ensured by Prof. Dr. Doina Cosma (1974-1983) and by Prof. Dr. Horaţiu Doroga (1983-1989).

The funds of libraries on current medical literature were also considerably diminished. The specialty books were even fewer and the newer ones were usually held by the department heads. There were several specialized journal titles, but not enough for the needs of many readers. For Dentistry and Maxillofacial Surgery there was only one magazine, in a sufficient number of copies. It was the Soviet magazine "Stomatologhia", a very knowledgeable magazine but with poor quality paper and iconography from which it was impossible to understand precisely what was to be shown.

In these circumstances, the overwhelming majority of the teaching physicians reached a degree of boredom that slowed scientific progress. Those who, however, had an interest in scientific news or did their PhD theses, appealed, through personal letters, to the authors of articles found in the bibliographic references of books or magazines. As a rule, they were asked to submit their articles "in extenso". Some of the authors responded, but most did not. Such a situation was demobilizing and, of course, it was reflected in the quality of the activity of the teaching staff and the level of healthcare.

The year 1989 brought fundamental changes. It came with bad and good. The evils were related to the anarchy that immediately followed the event that was called the "Romanian Revolution". Immediately after the event, the State abruptly declined its responsibility in many respects. Hospitals, for the most part, were in even greater pain, except for those which, at that time, had registered representatives at the level of the Sanitary Directorate. They directed material support to their clinics. Some clinics have reached the limit of survival due to lack of medicines and sanitary materials. The situation was particularly concerning for hospitals with a surgical profile.

Maxillofacial surgery was one of the most affected sections. The cause also resided in the fact that it was seen and classified in the category of "small surgery". The aid we received from abroad, for the most part, was damaged (tools) or outdated (sanitary materials). Some of them were from the war period (1940-1944).

Among the good things that appeared at that time was the opening of borders and relations with the West, which meant the vital breath of oxygen. At that time, Romania was viewed with compassion for all those who suffered.

Taking advantage of this, we contacted our counterparts in the West, including many of our former students there, to help us with those needed for the clinic. Most of them answered our calls. Some of us got to leave every holiday in the West with our personal cars to get back with them packed with medicines, tools or sanitary supplies that helped us survive from one vacation to another.

The best thing that happened after 1989 was the freedom to communicate with counterpart clinics in the West and with the scientific and professional societies there. The desire to see at what level we were in relation to them was a major wish. As expected, the differences were overwhelming. Therefore, our main objective was called "Recovery". I changed the paradigm that "the head of the department and the clinic must be the first one to go to training (recovery) and that, by returning with a lot of knowledge and applying them, he will get rapid recovery." We considered that the basis of the clinical and didactic pyramid - young people - was the most important and future resource. As an agreement between us, some went to various clinics in the West, while the others stayed there, completing the activity of the departed.

Thus, in a very short time, we obtained a professional recovery that we did not expect. Through the knowledge we have brought and implemented in the clinic, in many areas of Romanian oral and maxillofacial surgery, I have taken over the national spot. The programs and summaries of the national and international scientific events that we took part in from 1992-93 are edifying in this regard. In addition, we have connected to European, American and Asian international scientific and professional societies. Leading personalities of maxillofacial surgery such as Prof. Dr. Rudolf Fries or Prof. Dr. Julio Acero have made an essential contribution to our connection in the international professional environment.

In this way we have come to have national priority in many areas such as the implementation of computer tomography and nuclear magnetic resonance in oral and maxillofacial pathology, the approach of malignant tumors of the oral floor with evolution in the pharynx, the elaboration of an original procedure of reconstruction of the tongue and the oral floor, followed by important tumor resections, approach of maxillary tumors with extended evolution at the base of the skull, reconstruction of massive losses of oral and maxillofacial tissues by microsurgical methods, use of stem cells in the bone regeneration of the jaws, total upper osteotomy of the upper jaw in the dentomaxillary disharmony, surgical treatment of maxillary fractures, osteogenesis by elastic traction of the mandible in children with facial asymmetry, customized craniofacial reconstructions based on three-dimensional medical models, etc.

With these achievements we come to honor the 100th year of the existence of Romanian medical education in Cluj-Napoca. 


\section{References}

1. Iacobovici I. Cuvântare la deschiderea Congresului de Stomatologie [Opening speech at the Congress of Dentistry], 29-30 May 1943. Revista Română de Stomatologie. 1943;3:72-73.

2. Bilaşcu G. Hemoragiile banale şi hemofilice. Tratamentul [Common and hemophiliac hemorrhages. Treatment]. Clujul Medical. 1922;1-2:43-47.

3. Aleman I. Dosar examen pentru Docenţă şi Agregaţie [Examination papers for obtainment of Docent and Aggregation academic titles]. (Family archive).

4. Iacobovici I. Propedeutică chirurgicală [Surgical propedeutics]. Clujul Medical. 1927;11:560.

5. Aleman I. Protezele de rezecţie [Resection prostheses]. Revista Stomatologică, 1934;1:1-21.
6. Aleman I. Rezecțiile în maxilarul inferior şi tratamentul lor protetic [Resections in the lower jaw and their prosthetic treatment]. Clujul Medical. 1928;1:22-27.

7. Klima F. Tratamentul fisurii palatine. Teză de Doctorat în Medicină şi Chirurgie [Treatment of palatal fissure. PhD Thesis], Cluj, 1934.

8. Rotaru A, Rotaru H. Biography of Professor Cornel Tiberiu Opriş. Professional maturity. Clujul Med. 2017;90:235-240.

9. Opriş C. Povestea vieţii mele [My life's story]. Family's archive.

10. Rotaru A, Băciuț G, Rotaru H. Chirurgie Maxilo-Facială [Maxillofacial surgery]. Vol. I. Editura Medicală Universitară "Iuliu Haţieganu" Cluj-Napoca; 2003: pp. 54.

11. Horch HH. Mund-Kiefer-Gesichtschirurgie. Vol. I. UrbanSchwarzenberg, Munchen, 1990. 